Diabetologia 8, 342-348 (1972)

(C) by Springer-Verlag, 1972

\title{
Day-to-Day Variation of Continuously Monitored Glycaemia: A Further Measure of Diabetic Instability*
}

\author{
G.D. Molnar, W.F. Taylor, M.M. Ho \\ Mayo Clinic and Mayo Foundation, Rochester, Minnesota, U.S.A. \\ Received: April 25, 1972, accepted: June 22, 1972
}

Summary. Differences between paired blood glucose values during two successive 24 -h periods of continuous blood glucose analysis were investigated during 22 studies in seven unstable diabetics, three stable diabetics, and three normal subjects. The absolute means (without regard to sign) of daily differences (MODD) were high in unstable diabetics $(36.6$ to $158.1 \mathrm{mg} / 100 \mathrm{ml}$ ), intermediate in stable diabetics $(10.2$ to $35.1 \mathrm{mg} / 100 \mathrm{ml})$, and low in normals $(6.2$ to $8.2 \mathrm{mg} / 100 \mathrm{ml})$. MODD was a measure of the blood glucose changes resulting from day-to-day variation in response to therapy that was kept as constant as possible. When therapy was deliberately intensified through the use of four daily injections of short-acting insulin, MODD decreased in five of six such experiments. In two diabetics retested at intervals of 5 to 7 months without change in insulin regimen, MODD values remained similar. MODD quantifies another characteristic of blood glucose behaviour, the between-day variability; this is an important complement of the mean amplitude of glycaemic excursions (MAGE, a measure of within-day variability) and of the mean blood glucose concentration, MBG (the overall level of glycaemia during the variability measurements).

Variation quotidienne de la glycémie enregistrée en continu: une mesure supplémentaire de l'instabilité diabétique

Résumé. L'analyse continue de la glycémie pendant deux périodes successives de 24 heures a permis d'établir la différence entre les valeurs couplées du glucose sanguin pour chaque période, au cours de 22 études chez 7 diabétiques instables, 3 diabétiques stables et 3 sujets normaux. Chez les diabétiques instables, la moyenne absolue des différences quotidiennes (MADQ) était élevée (36.6 à $158.1 \mathrm{mg} / 100 \mathrm{ml}$ ), intermédiaire chez les diabétiques stables (10.2 à $35.1 \mathrm{mg} / 100 \mathrm{ml}$ ) et basse chez les sujets normaux $(6.2$ à $8.2 \mathrm{mg} / 100 \mathrm{ml})$. La MADQ mesurait les changements de la glycémie dus aux variations quotidiennes de la réponse au traitement, lequel était aussi constant que possible. Dans six expériences, l'augmentation intentionnelle du traitement, par l'injection d'insuline rapide 4 fois par jour, provoqua une diminution de la MADQ à cinq reprises. Chez deux diabétiques étudiés à intervalles de 5 à 7 mois, sans changement de traitement, la
MADQ est restée semblable. La MADQ caractérise aussi la variabilité quotidienne de la glycémie, complément important à l'amplitude moyenne des variations du glucose sanguin pendant la journée (AMVG) et à la glycémie moyenne (GSM) au cours de la même période.

Tag-zu-Tag-Schwankungen des kontinuierlich gemessenen Blutzuckers: ein weiteres Maß für die Labilität des Diabetes

Zusammenfassung. Es wurden die Differenzen zwischen den beiden einander zugeordneten Blutzuckerwerten während zwei aufeinanderfolgender 24-Stunden Perioden einer kontinuierlichen Blutzuckeranalyse bei 22 Untersuchungen an sieben labilen Diabetikern, drei stabilen Diabetikern und drei Normalpersonen untersucht. Der absolute Durchschnittswert der täglichen Differenzen (MODD) (ohne das Vorzeichen zu beachten) war bei den labilen Diabetikern hoch $(36.6$ bis $158.1 \mathrm{mg}$ / $100 \mathrm{ml})$, weniger hoch bei den stabilen Diabetikern $(10.2$ bis $35.1 \mathrm{mg} / 100 \mathrm{ml}$ ) und niedrig bei den Normalen ( $6.2 \mathrm{bis}$ $8.2 \mathrm{mg} / 100 \mathrm{ml}$ ). Der Mittelwert der täglichen Unterschiede (MODD) war ein Maß der Änderungen der Blutglucosekonzentration auf Grund von Tag-zu-Tag-Schwankungen als Folge der Therapie, die so konstant wie möglich gehalten wurde. Wenn die Therapie beträchtlich intensiviert wurde, indem vier tägliche Insulininjektionen eines kurzwirkenden Insulins gegeben wurden, verminderte sich der Mittelwert bei 5 von 6 Untersuchungen. Bei zwei Diabetikern, die nach 5 bis 7 Monaten ohne Veränderungen der Insulinbehandlung wieder untersucht wurden, blieben die MODD-Werte ähnlich. Sie sind ein Maß einer weiteren Eigenschaft dos Blutzuckerverhaltens, nämlich der Schwankungen von Tag zu Tag. Dies ist eine wichtige Ergänzung zu den Messungen der durchschnittlichen Amplitude der Blutzuckerkurve (MAGE, ein Maß der Schwankungen innerhalb eines Tages) und der durchschnittlichen Blutzuckerkonzentration, MBG (durchschnittlicher Blutzuckerspiegel während der Messung der Blutzuckerschwankungen).

Key words: Blood glucose variability, Continuous blood glucose analysis, Insulin therapy, Unstable diabetes.
After 50 years of the therapeutic use of insulin, restoring normal blood glucose homoeostasis in diabetic patients has not been achieved $[1,2]$. This is particularly so in diabetics who are most lacking in endogenous insulin [3]. If progress is to be made in therapy

* This investigation was supported in part by Research Grant AM-10152 from the National Institutes of Health, Public Health Service, and by a grant from the Endicott-Bohn Foundation. toward normal blood glucose homoeostasis achievement, the causes of the differences between normal and deranged behaviour must be identified and measured [4]. In an effort to determine why current "optimal" diabetic therapy fails to achieve blood glucose normalization in more than just a general [5] or an indirect way [6], we have performed studies with continuous monitoring of blood glucose and have attempted to identify and measure the differences between diabetic 
and normal blood patterns $[1,2]$. A previous report dealt with higher mean levels of glycaemia and the wider blood glucose fluctuations of diabetics [2]. This report identifies and quantifies the greater day-to-day variability of diabeties.

Recently, we have described, as a measure of blood glucose regulatory stability, the mean amplitude of glycaemic excursions (MAGE) during continuous blood glucose monitoring of ambulatory, fed subjects under standardized living conditions [2]. In that work, we were concerned mainly with within-day blood glucose swings, although day-to-day changes also were examined. We observed that some diabetic patients with wide within-day blood glucose swings (high MAGE values) had relatively more consistent blood glucose patterns from day to day than did others with similar MAGE values. Conversely, some patients with lower MAGE values had less consistent blood glucose patterns from day to day. Evidently, MAGE and the diurnal mean blood glucose level do not identify or quantify the day-to-day component of blood glucose variation. Others also have considered day-to-day blood glucose variation $[5,7-9]$ in attempting to quantify diabetic instability, but on the basis of intermittent blood glucose determinations and generally under less highly standardized conditions.

We report herein our findings concerning the mean of daily blood glucose differences (MODD) of paired blood glucose values on successive days. As anticipated in a previous report [4], this new parameter seems to be a useful additional quantification of blood glucose regulatory stability, along with MAGE and the diurnal mean blood glucose level.

\section{Methods}

Our methods of study, which combined prolonged metabolic investigations with 48-hour-long continuous blood glucose monitoring, as well as the clinical features of the subjects we investigated, have been described in detail $[1,10]$. Two programs of clinically optimal therapy with insulin were developed and used for the unstable diabetics [1]. One was the once or twice daily injection of intermediate-acting insulin, with or without short-acting insulin, from the same syringe. The other was the four times daily injection of short-acting insulin. The time schedule of insulin injections, meals, exercise, and sleep was consistent throughout the studies (Fig. 1 through 4). The diet provided major meals of equal calories and equal composition (by weight and analysis) of carbohydrate, of protein and fat content within each day and between days [1]. The exercise consisted of a 1-hour walk in the third postprandial hour. The subjects were trained to walk at a similar pace during each exercise period [1]. The analytic methods, including the continuous automated blood glucose monitoring, also have been reported $[1,11]$. A quantification of blood glucose regulatory stability (or diabetic instability) also has been reported [2].

In the present study, both previously reported and additional data ${ }^{1}$ were examined as follows. Blood glucose values at 5-minute intervals (taken from the

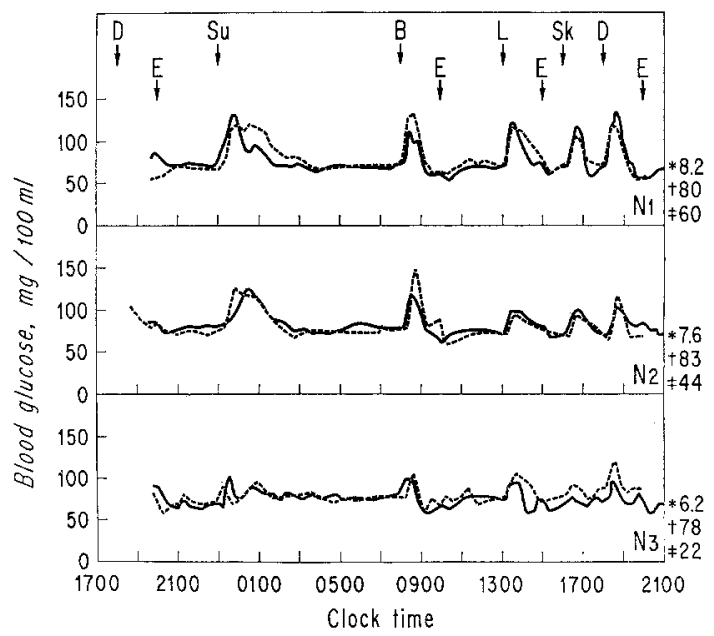

Fig. 1. Blood glucose curves of three normal subjects during $48 \mathrm{~h}$ of continuous blood glucose analysis. Solid line $=$ first $24 \mathrm{~h}$; interrupted line $=$ second $24 \mathrm{~h} ; \mathrm{B}=$ breakfast $; \mathrm{L}=$ lunch; $\mathrm{Sk}=$ snack $; \mathrm{D}=$ dinner $; \mathrm{Su}=$ supper $\mathrm{E}=$ exercise for $1 \mathrm{~h} .{ }^{*}=\mathrm{MODD}, \mathrm{mg} / 100 \mathrm{ml} ; \dagger=$ mean blood glucose $\mathrm{mg} / 100 \mathrm{ml} ; \neq=\mathrm{MAGE}, \mathrm{mg} / 100 \mathrm{ml}$

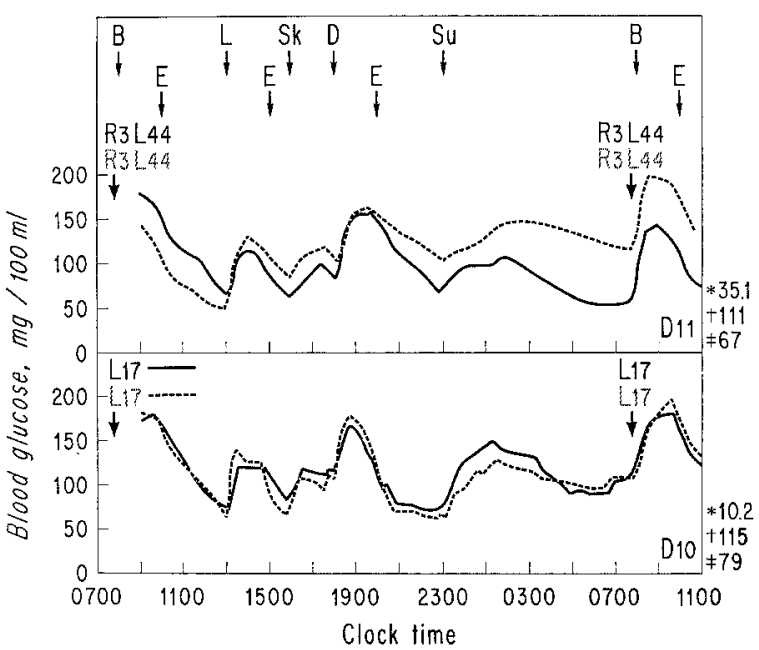

Fig. 2. Blood glucose curves of two stable diabetics during $48 \mathrm{~h}$ of continuous blood glucose analysis. Treatment was predominantly with intermediate-acting insulin injected once daily. $\mathbf{R}=$ regular insulin; $\mathbf{L}=$ lente insulin. The first $24 \mathrm{~h}$ dose is in solid letters and numbers; the second $24 \mathrm{~h}$ dose is in dotted letters and numbers. Other symbols as in Fig. 1

continuous record) were matched with the corresponding values $24 \mathrm{~h}$ later, and the absolute differences (without regard to sign) of the matched pairs were

1 Three studies not previously reported (one each in patients D1, D2, and D4) are included in this report). 


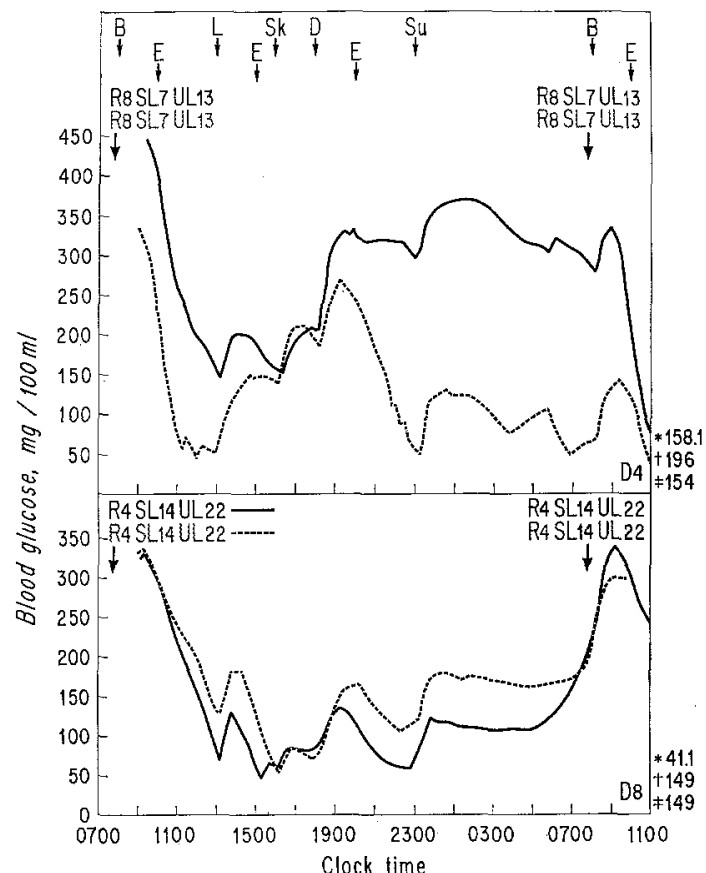

Fig. 3. Blood glucose curves of two unstable diabetics obtained during $48 \mathrm{~h}$ of continuous blood glucose analysis. $\mathrm{SL}=$ semilente insulin. Insulin was injected once daily. Symbols as in Figs. 1 and 2

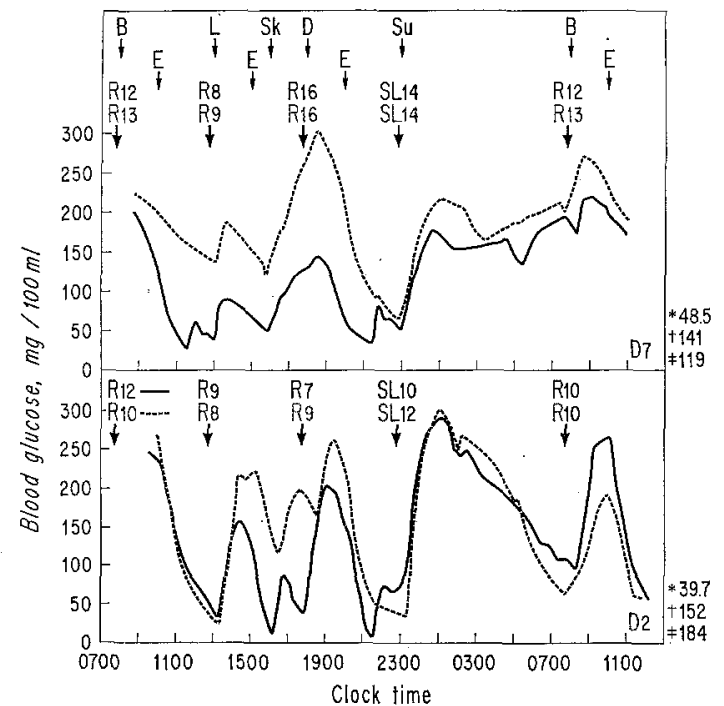

Fig. 4. Blood glucose curves of two unstable diabetics obtained during $48 \mathrm{~h}$ of continuous blood glucose analysis. Treatment was with short-acting insulin injected four times daily. Symbols as in Fig. 1 through 3

determined. The mean of these differences (MODD) and their dispersion about the mean were calculated. ${ }^{2}$

2 We are aware of analogous measures of between-day blood glucose variability by Izzo and Crump [7] and by Hedner and Nordón [9] involving the variance of measure. ments between days. We chose our measure because of its simplicity. Analyses were also carried out by using the method of Hedner and Nordén [9]; results were similar to those using our method.
Nonparametric rank-sum tests and Student's "t" test were used to test hypotheses as deemed appropriate.

\section{Results}

Relevant clinical and analytic data are summarized in Table 1. Daily insulin dosage and differences, during successive 24 -h periods, in paired blood glucose values (MODD) are shown in Table 2.

The Figures illustrate typical pairs of consecutive 24-h continuous blood glucose records. Fig. 1 shows the patterns for three normal subjects (N1, N2, and N3); all three subjects had low values for MODD and for the other parameters noted in Table 1. Fig. 2 shows blood glucose patterns for two stable diabetics; one (D10) had a low MODD value and the other (D11) had an intermediate MODD value, despite similar MAGE and mean blood glucose values (Table 1). Fig. 3 shows blood glucose patterns for two unstable diabetics who were treated with intermediate-acting insulin regimens; in one (D4), the MODD value was high, and in the other (D8), it was intermediate. Their MAGE values were similar although their mean blood glucose values were different. Figure 4 shows blood glucose patterns for two other unstable diabetics, during treatment with short-acting insulin regimens. The higher MODD value is associated with the lower MAGE value (D7), and the lower MODD value is associated with the higher MAGE value (D2); the mean blood glucose values were similar.

The values of MODD varied significantly among the three groups of subjects $(P<0.001$; Kruskal-Wallis test). They were significantly higher for unstable diabetics than for the other two groups $(P<0.01)$.

To determine whether changes in MODD values occurred merely as the result of day-to-day changes in insulin dosage (Table 2), the data from studies without day-to-day dosage changes were reexamined. There still was a highly significant difference (by rank-sum test) in MODD between unstable diabetics as one group and stable diabetics and normal subjects as another group $(P \approx 0.001)$. Therefore, minor day-today changes in insulin dosage probably do not influence the difference in MODD values between these groups.

The effect of change in insulin therapy on MODD values was compared from one study to the next in the same unstable diabetics. The change was from clinically suboptimal therapy with one or two daily injections of intermediate-acting insulin to intensified, clinically optimal therapy with four daily injections of short-acting insulin [1,2]. Decreased mean blood glucose and urinary glucose values resulted (Table 1), but no significant decrease in MAGE could be achieved [2]. In all but one instance (D1), such intensified therapy also resulted in decreased values of MODD (Table 2). However, the MODD did not differ significantly on the two regimens ( $P \approx 0.06$ by rank-sum test; $P \approx 0.17$ by " $\mathrm{t}$ " test). 
A further comparison was made when the regimen of both short-acting insulin therapy and the timing of insulin administration were changed as follows in patient D4: (1) insulin injections and meals were given at 6-h intervals instead of the usual 5-h interval between meals and a 9 -h interval at night $[1,2]$; and (2) regular insulin was given before every meal, instead of the usual regular insulin before daytime meals and semilente insulin before the bedtime meal $[1,2,6]$. The result was an increase in MODD, mean blood glucose, and MAGE, but the urinary glucose value remained as low as before (Tables 1 and 2 ). lyzed for the completeness with which they separated the groups of subjects (Fig. 5). MODD differentiated more consistently among groups of subjects (normals, stable, and unstable diabetics) than did the differences between successive 24-h mean blood glucose, MAGE, and urinary glucose values.

\section{Comment}

Day-to-day blood glucose variation as measured by MODD in this study is intended to illustrate an im-

Table 1. Relevant data for subjects studied

\begin{tabular}{|c|c|c|c|c|c|}
\hline $\begin{array}{l}\text { Subject; } \\
\text { regimen }\end{array}$ & $\begin{array}{l}\text { Age (yr); } \\
\text { sex }\end{array}$ & $\begin{array}{l}\text { Diabetes, } \\
\text { duration (yr) } \\
\text { \& stability }\end{array}$ & $\begin{array}{l}48-\mathrm{h} \mathrm{MBG} \\
(\mathrm{mg} / 100 \mathrm{ml})\end{array}$ & $\begin{array}{l}48-h \text { MAGE } \\
(\mathrm{mg} / 100 \mathrm{ml})\end{array}$ & $\begin{array}{l}48-\mathrm{h} \text { mean } \\
\text { urinary } \\
\text { glucose } \\
\text { (gm/24 h }\end{array}$ \\
\hline \multicolumn{6}{|l|}{ Normals } \\
\hline $\mathrm{N} 1$ & $24 \mathrm{M}$ & & 80 & 60 & 3.9 \\
\hline N2 & $57 \mathrm{~F}$ & & 83 & 44 & 2.2 \\
\hline N3 & $24 \mathrm{~F}$ & & 78 & 22 & 2.2 \\
\hline \multicolumn{6}{|c|}{ Stable diabetics } \\
\hline D9 & $47 \mathrm{~F}$ & $11 \mathrm{~S}$ & 110 & 82 & 2.4 \\
\hline D10 & $55 \mathrm{M}$ & $14 \mathrm{~S}$ & 115 & 79 & 2.9 \\
\hline D11 & $70 \mathrm{~F}$ & $18 \mathrm{~S}$ & 111 & 67 & 2.1 \\
\hline \multicolumn{6}{|c|}{ Unstable diabetics } \\
\hline \multirow{3}{*}{ 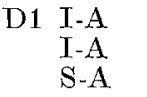 } & $45 \mathrm{~F}$ & $41 \mathrm{HU}$ & 208 & 200 & 15.9 \\
\hline & & & 214 & 225 & 54.2 \\
\hline & & & 145 & 198 & 13.3 \\
\hline \multirow{3}{*}{ D2 $\begin{array}{r}\mathrm{I}-\mathrm{A} \\
\mathrm{S}-\mathrm{A} \\
\mathrm{S}-\mathrm{A}\end{array}$} & $44 \mathrm{~F}$ & $12 \mathrm{HU}$ & 244 & 184 & 53.7 \\
\hline & & & 152 & 185 & 29.1 \\
\hline & & & 155 & 197 & 16.9 \\
\hline D3 S-A & $20 \mathrm{~F}$ & $15 \mathrm{HU}$ & 223 & 199 & 9.3 \\
\hline D4 $\underset{\mathrm{S}-\mathrm{A}}{\mathrm{I}-\mathrm{A}}$ & $59 \mathrm{~F}$ & $20 \mathrm{U}$ & 196 & 154 & 44.4 \\
\hline S-A & & & 113 & 121 & 2.7 \\
\hline$S-A^{d}$ & & & 170 & 168 & 3.0 \\
\hline \multirow{2}{*}{$\begin{array}{l}\text { D6 } \\
\text { S-A } \\
\text { S-A }\end{array}$} & $36 \mathrm{M}$ & $24 \mathrm{U}$ & 170 & 169 & 9.3 \\
\hline & & & 101 & 123 & 3.6 \\
\hline \multirow{2}{*}{ D7 $\begin{array}{r}\text { I-A } \\
\text { S-A }\end{array}$} & $21 \mathrm{M}$ & $12 \mathrm{U}$ & 146 & 119 & 23.0 \\
\hline & & & 141 & 134 & 17.4 \\
\hline \multirow{2}{*}{ 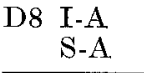 } & $25 \mathrm{~F}$ & $9 \mathrm{U}$ & 149 & 149 & 14.3 \\
\hline & & & 119 & 119 & 3.9 \\
\hline
\end{tabular}

a I-A = intermediate-acting insulin injected once or twice/24 h; S-A = shortacting insulin injected four times $/ 24 \mathrm{~h}$

b $\mathrm{S}=$ stable; $\mathrm{U}=$ unstable; $\mathrm{HU}=$ highly unstable

c These measurements, by a ferricyanide AutoAnalyzer method, have a high but individually constant blank [12]; this explains the apparently high values in the normal subjects

d S-A regimen with insulin and meals at $6-h$ intervals

When the regimen of insulin therapy was kept unchanged from one study to another (although during the intervening 5 to 7 months the insulin dosage did change slightly [Table 2]), MODD values remained remarkably similar in patients D1 and D2. During these studies, MAGE and mean blood glucose values also remained similar, but daily variation in MAGE changed considerably.

To evaluate whether MODD provides a more useful index of day-to-day blood glucose variability than the day-to-day differences in 24-h MAGE in mean blood glucose or in urinary glucose, these values were ana- portant measure of diabetic instability and to provide numerical characterization of the difference between consecutive nyctohemeral blood glucose curves. Because of the arduous nature of continuous blood glucose monitoring, these studies had to be limited to two consecutive 24-h periods. This limitation does not impair the consideration of MODD as a parameter of diabetic instability to be applied to future studies of longer duration. However, it does limit generalizations beyond the available data. Fortunately, the present investigation included simultaneous, albeit intermittent, measurements of other variables such as 
urinary glucose and plasma IRI concentrations, so that the interrelationships of these other variables to MODD could be analyzed. The analysis relating to urinary glucose has been presented under Results; the interrelationships with IRI form part of another report [13].

MODD is a parameter of blood glucose regulatory stability that complements MAGE and mean blood glucose. MODD best quantifies day-to-day blood glucose variability under conditions designed to minimize blood glueose change [1]. MODD measures the blood glucose changes resulting from variations in

Table 2. Daily insulin dosage and MODD values, during successive 24-h periods

\begin{tabular}{|c|c|c|c|c|c|}
\hline \multirow{2}{*}{$\begin{array}{l}\text { Subject; } \\
\text { regimen }^{a}\end{array}$} & \multirow{2}{*}{\multicolumn{2}{|c|}{$\begin{array}{l}\text { Insulin dosage } \\
\text { (units } / 24 \mathrm{~h} \text { ) }\end{array}$}} & \multicolumn{3}{|c|}{$\operatorname{MODD}(\mathrm{mg} / 100 \mathrm{ml})$} \\
\hline & & & Mean & $\begin{array}{l}\text { No. of } \\
\text { pairs }\end{array}$ & SD \\
\hline \multicolumn{6}{|l|}{ Normal } \\
\hline & & & 7.6 & 283 & 7.1 \\
\hline & & & 6.2 & 282 & 5.8 \\
\hline \multicolumn{6}{|c|}{ Stable diabetics } \\
\hline D9 & $\begin{array}{l}\text { P75 } \\
\text { T250 }\end{array}$ & $\begin{array}{l}\text { P75b } \\
\text { T250b }\end{array}$ & 23.6 & 287 & 13.6 \\
\hline D10 & 17 & 17 & 10.2 & 277 & 6.9 \\
\hline D11 & 47 & 47 & 35.1 & 273 & 19.9 \\
\hline \multicolumn{6}{|c|}{ Unstable diabetics } \\
\hline D1 I-A & 33 & 35 & 53.7 & 286 & 48.9 \\
\hline $\mathrm{I}-\mathrm{A}$ & 27 & 27 & 50.2 & 275 & 37.9 \\
\hline $\mathrm{S}-\mathrm{A}$ & 33 & 36 & 97.1 & 284 & 64.0 \\
\hline D2 I-A & 33 & 34 & 63.2 & 280 & 44.7 \\
\hline S.A & 38 & 39 & 39.7 & 271 & 36.9 \\
\hline S.A & 41 & 41 & 37.8 & 274 & 25.3 \\
\hline D3 S-A & 38 & 38 & 51.5 & 282 & 35.2 \\
\hline D4 I-A & 28 & 28 & 158.1 & 278 & 85.0 \\
\hline S. & 22 & 22 & 36.9 & 271 & 23.8 \\
\hline$S-A^{c}$ & 20 & 20 & 59.8 & 279 & 32.3 \\
\hline D6 I-A & 34 & 36 & 44.6 & 283 & 38.3 \\
\hline S-A & 28 & 28 & 37.5 & 274 & 25.6 \\
\hline D7 I-A & 63 & 63 & 70.3 & 278 & 39.8 \\
\hline S-A & 50 & 52 & 48.5 & 281 & 37.2 \\
\hline D8 I-A & 40 & 40 & 41.1 & 274 & 22.9 \\
\hline S.A & 33 & 33 & 36.6 & 276 & 30.9 \\
\hline
\end{tabular}

a $\mathbf{I}-\mathbf{A}=$ intermediate-acting insulin injected once or twice $/ 24 \mathrm{~h} ; \mathrm{S}-\mathrm{A}=$ short-acting insulin injected four times/ $24 \mathrm{~h}$

b $\mathrm{P}=$ phenformin; $T=$ tolazamide $(\mathrm{mg} / 24 \mathrm{~h})$

c $\mathrm{S}$-A regimen with insulin and meals at 6 -h intervals

response to therapy that has been kept as constant as possible. MAGE measures the average extent of blood glucose swings. In unstable diabetics, these blood glucose swings are wide because of excessive increases in blood glucose as a result of too little insulin action, usually soon after food intake. In the same subjects, the blood glucose swings are also wide because of excessive decreases in blood glucose as a result of too much insulin action, usually late after food intake. Thus, MAGE measures the relative inadequacy of therapy in keeping blood glucose excursions within normal limits. MAGE does not measure the variabi- lity with which blood glucose excursions occur. (The coefficient of variation of MAGE was similar in the three groups of subjects [2]). The magnitude of blood glucose excursions, generally but not necessarily, tended to be more variable (both within and between days) when the excursions are wider (Fig. 1 through 4). Instead of relying on the $\mathrm{M}$ value $[2,5,8]$, which lumps the quantitative assessment of a diabetic's adequacy of blood glucose regulatory compensation, we have aimed for separate quantifications of the following components: 1 . the mean level to which diurnal glycaemia has been decreased by therapy, given by mean blood glucose; 2. the within-day extent of postprandial blood glucose swings, given by MAGE; and 3. the day-to-day variation in glycaemia, given by MODD. We previously found that, on intensification of insulin therapy, individually irreducible MAGE values as well as frequency and severity of hypoglycaemic episodes limited the extent to which mean blood glucose could be decreased in unstable diabetics. While MODD values also separated the groups of subjects, this parameter (somewhat like the mean

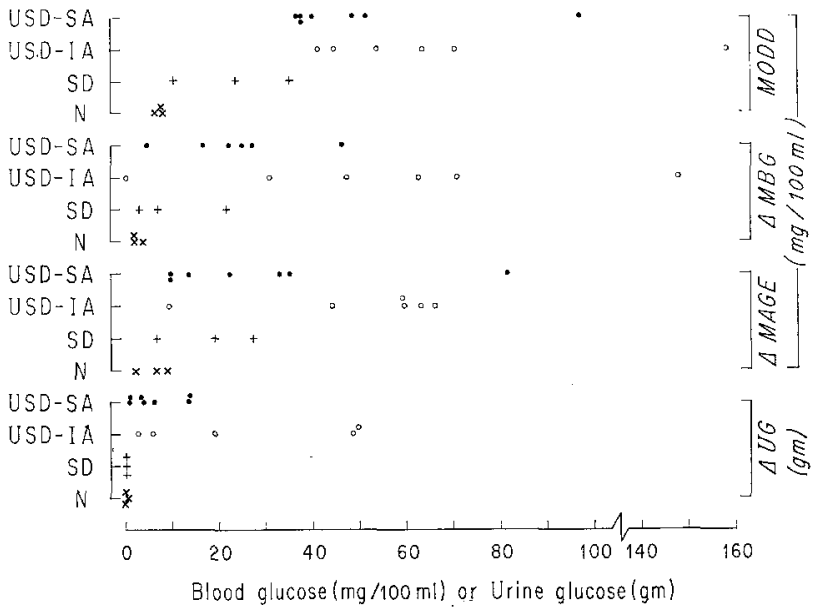

Fig. 5. Comparisons of MODD with day-to-day differences $(\Delta)$ in 24-h MAGE, mean blood glucose (MBG), and urine glucose (UG) values. Symbols: $X=$ normals; $+==$ stable diabetics; circles $=$ unstable diabetics. Open circles are values during therapy with intermediate-acting insulin regimen (I-A); closed circles are values during therapy with short-acting insulin regimen (S-A)

blood glucose) could be varied, and intensification of treatment usually, but not always, tended to decrease it. On the same regimen of therapy, MODD appeared relatively stable for those subjects in whom this was tested.

Thus, MODD quantifies the clinical phenomenon of between-day variability of blood glucose behaviour under conditions of relative constancy of experimental conditions. MODD can be relatively independent of MAGE because some patients (for example, D2 and D4 on the short-acting insulin regimen) can have wide blood glucose swings within days but relatively less 
wide blood glucose differences between days. Likewise, other patients (D7 and D11 on the intermediateacting insulin regimen) can have relatively narrow blood glucose swings within days but relatively wide blood glucose differences between days. The mean blood glucose supplies important background information about the degree to which mean glycaemia approached normal as the other two parameters were measured. With these three values, it is possible to describe quantitatively a diabetic's degree of blood glucose regulatory instability or stability.

The causes of within-day blood glucose changes being relatively independent of between-day blood glucose changes are not known. The wider-than-normal within-day blood glucose fluctuations in diabetics reflect the lack of adaptation between the moment-tomoment need for and supply of insulin. The greaterthan-normal between-day variations indicate that, despite constant treatment, the results of treatment are abnormally variable. Consideration of the presumed causes of each of these types of blood glucose changes suggests that they are so related as to make various degrees of interdependence possible. The presumed principal cause of wider-than-normal withinday blood glucose variation is insufficient insulin action soon after meals and excessive insulin action late after meals. A partial confirmation of this hypothesis is now at hand from measurement of IRI levels in insulin-treated patients [13]. Additional factors which may widen the amplitude of glycaemic excursions are: 1. influences augmenting early postprandial glycaemia, including hormonal anti-insulin factors (such as glucagon, epinephrine, and growth hormone), rapid gastrointestinal absorption of carbohydrate [14], and augmented gluconeogenesis and 2. influences decreasing late postprandial glycaemia, including muscular exercise and glycosuria. The presumed principal causes of wider-than-normal between-day blood glucose variations may be day-to-day changes of insulin delivery to and effectiveness in the liver and peripheral tissues. Furthermore, day-to-day variation in the factors presumed to be affecting the width of glycemic excursions could also contribute to the variation in day-to-day blood glucose patterns.

Others have used measures of day-to-day variability to quantify diabetic instability $[4,6-8]$, but these all were based on intermittent blood glucose determinations and on 4 to 9 values per $24 \mathrm{~h}$ in contrast to our 288 values. However, some of the studies extended from 3 to 6 days $[5,7,9]$. Quantitative analysis of our continuously collected urinary glucose, ketone body, and nitrogen data, for periods before, during, and after our 48-h continuous blood glucose analysis, suggests that the 48-h-long continuous blood glucose studies were representative of the 6-day-long balance periods [1]. However, because the correlation between urinary glucose variation from day to day and MODD values was not sufficiently high to be statistically significant, it is not possible to state how repre- sentative the observed MODD value for $48 \mathrm{~h}$ might be of the 6-day periods of study. Studies in progress show promise that adequate, although less precise, quantification of diabetic instability may be feasible with a relatively small number of blood glucose values obtained, with identical timing, on successive days [15]. These additional studies reveal the feasibility of applying the present methods of analysis to intermittently obtained data, so that patients could be studied (for both investigative and practical clinical purposes) over more extended periods than has heretofore been possible because of the limits imposed by continuous blood glucose analysis $[1,11]$.

In this context it is important to acknowledge that, for clinical data to be interpretable, they need to be accumulated with sufficient precision and under interpretable conditions. With cooperative patients and proper emphasis on the importance of making accurately timed observations, while therapeutic conditions (insulin, diet, and exercise) are kept similar from day to day, the practical clinical application of the lessons learned during these investigations has not been unduly difficult [15]. The difference between investigative and practical clinical data gathering may in this case be merely one of degree. For instance, the degree to which conditions are kept similar from day to day is somewhat more lax in the clinic or hospital than in the research ward. Because blood glucose levels respond to meals, exercise, and other activities, the sampling of blood must be related to the timing of these activities instead of to clock time if changes in timing of activities occur. Furthermore, the number of blood samplings has to be compatible with a level of discomfort acceptable even to a cooperative patient. It is reasonable to assume that patients who seek help because of genuine difficulties of regulating their diabetes are likely to be cooperative. Their physicians in turn need to recognize that quantification of blood glucose variability should include three elements: day-to-day changes, within-day changes, and overall level of glycaemia.

\section{References}

1. Molnar, G.D., Ackerman, E., Rosevear, J.W., Gatewood, L. C., Moxness, K. E.: Continuous blood glucose analysis in ambulatory fed subjects. I. General methodology. Proc. Mayo Clin. 43, 833-851 (1968).

2. Service, F.J., Molnar, G.D., Rosevear, J.W., Ackerman, E., Gatewood, L.C., Taylor, W.F.: Mean amplitude of glycemic excursions, a measure of diabetic instability. Diabetes 19, $644-655(1970)$.

3. Cremer, G.M., Molnar, G.D., Taylor, W.F., Moxness, K.E., Service, F.J., Gatewood, L.C., Ackerman, E., Rosevear, J.W.: Studies of diabetic instability. II. Tests of insulinogenic reserve with infusions of arginine, glucagon, epinephrine, and saline. Metabolism 20, $1083-1098$ (1971).

4. Ackerman, E., Gatewood, L.C., Molnar, G.D., Rosevear, J.W., Service, F.J.: Quantitative measures of instability of blood glucose regulation (abstract). Fed. Proc. 27, 565 (1968). 
5. Schlichtkrull, J., Munck, O., Jersild, M. : The M-value, an index of blood-sugar control in diabetics. Acta med. scand. 177, 95-102 (1965).

6. Molnar, G.D., Gastineau, C.F., Rosevear, J.W., Moxness, K.E.: Quantitative aspects of labile diabetes. Diabetes 14, 279-288 (1965).

7. Izzo, J.L., Crump, S.L.: Clinical comparison of modified insulins. J. clin. Invest. 29, 1514-1527 $(1950)$.

8. Czyzyk, A., Ponikowska, I.: La signification des valeurs particulières de la glycémie dans le cycle glycemique journalier. Acta Diabetol. Lat. 4, 374385 (1967).

9. Hedner, L. P., Nordén A.: Analysis of variance applied to blood glucose values for assessing insulin preparations and state of lability in diabetes. Diabetologia $\mathbf{5}$, $108-115$ (1969).

10. Service, F.J., Molnar, G.D., Rosevear, J.W., Ackerman, E., Taylor, W.F., Cremer, G.M., Moxness, K.E.: Continuous blood glucose analysis in ambulatory fed subjects. II. Effects of anticoagulation with heparin. Proc. Mayo Clin. 44, 466-477 (1969).

11. Rosevear, J.W., Pfaff, K.J., Service, F.J., Molnar,
G.D., Ackerman, E.: Glucose oxidase method for continuous automated blood glucose determination. Clin. Chem. 15, 680-698 (1969).

12. Molnar, G.D., McGuckin, W.F., Striebel, J.L., Gastineau, C.F.: Effects of therapeutic measures in a hyperlabile diabetic. Proc. Staff. Meet. Mayo Clin. 36, 45-61 (1961).

13. Molnar, G.D., Taylor, W.F., Langworthy, Alice: Plasma immunoreactive insulin patterns of insulintreated diabetics: Studies during continuous blood glucose monitoring. Unpublished data.

14. Vinnik, I.E., Kern, F., Jr., Sussman, K. E.: The effect of diabetes mellitus and insulin on glucose absorption by the small intestine in man. J. Lab. clin. Med. 66, $131-136$ (1965).

15. Molnar, G.D., Taylor, W.F., Langworthy, Alice: Blood glucose criteria of diabetes regulation: Comparison of discrete with continuously sampled values. Unpublished data.

\author{
G.D. Molnar, M.D. \\ Mayo Clinic \\ Rochester, Minnesota 55901 USA
}

